\title{
Effect of Jaundice Phototherapy on Intestinal Mucosal Bilirubin Concentration and Lactase Activity in the Congenitally Jaundiced Gunn Rat
}

\author{
PETER F. WHITINGTON'(24) \\ Division of Gastroenterology, Department of Pediatrics, University of Tennessee Center for the Health Sciences, \\ Memphis, Tennessee, USA
}

\begin{abstract}
Summary
The effect of phototherapy on intestinal mucosal bilirubin concentration and lactase activity in the Gunn rat was studied. Ten groups of six or seven animals each were studied. Heterozygous ( $\mathrm{Jj}$ ) and homozygous (jj) animals were given 24,48 , or $72 \mathrm{hr}$ of continuous phototherapy, and $\mathrm{Jj}$ and $\mathrm{jj}$ animals were given 24 and 48-hr sham control treatments. Phototherapy reduced serum bilirubin concentration by $53 \%$ at $24 \mathrm{hr}, 59 \%$ at $48 \mathrm{hr}$ and $68 \%$ at 72 hr. The mucosal concentration of bilirubin appeared to parallel the declining serum concentration and was lower in treated than in control $\mathbf{j j}$ animals. The jejunal and ileal lactase activity, expressed per $\mathrm{mg}$ protein, was not depressed by phototherapy. The lactase activity of jejunum and of ileum of treated ij as compared to treated $\mathrm{Jj}$ and control $\mathrm{jj}$ at 24 and $48 \mathrm{hr}$ and as compared to treated $\mathrm{Jj}$ at $72 \mathrm{hr}$ was never reduced; i.e., jejunal lactase activity in $\mathrm{jj}$ treated for $72 \mathrm{hr}$ was $15.1 \pm 4.2(\overline{\mathrm{x}} \pm$ S.D. $)$ units $/ \mathrm{g}$ protein as compared to $16.2 \pm 4.2$ for $\mathrm{Jj}$ treated for $72 \mathrm{hr}$ and $12.0 \pm 4.2$ for ij 48-hr control animals. The ratio of lactase to sucrase activity demonstrated a significant increase in lactase activity relative to sucrase in all animals treated for $\mathbf{4 8}$ or $\mathbf{7 2} \mathbf{~ h r}$. This latter effect is potentially due to alteration in the circadian rhythm while under constant irradiance.
\end{abstract}

These data convincingly demonstrate that the Gunn rat does not develop lactase deficiency consequent to phototherapy.

\section{Speculation}

These data support the hypothesis that acute intestinal secretion is important in the mechanism of diarrhea occurring during jaundice phototherapy by arguing against the role of lactase deficiency in that mechanism.

A recent study has estimated that $10 \%$ of infants born in the United States receive phototherapy for neonatal jaundice (8). Such therapy is associated with a significant $(9.5 \%)$ incidence of watery diarrhea (10). Increased fecal water loss (17) and decreased gut transit time (19) are characteristically observed in affected infants, but the pathogenesis of the process remains uncertain. Intestinal lactase deficiency has been found in some affected infants (1), but further investigation has indicated that lactose intolerance cannot be demonstrated in infants receiving phototherapy $(6,7)$. Therefore, the relationship between lactase deficiency and watery diarrhea occurring during jaundice phototherapy is not clearly established.

The congenitally jaundiced Gunn rat has been used as a model for nonconjugated hyperbilirubinemia, particularly in the elucidation of the mechanism of jaundice phototherapy $(14,18)$. The effect of phototherapy on the activity of intestinal lactase in the Gunn rat has also been investigated, appearing in abstract form (5). This latter work demonstrated that irradiation of jaundiced rats resulted in intestinal lactase deficiency and supported previous observations in human infants (1).

Phototherapy results in hepatic excretion of nonconjugated bilirubin (18). We have previously reported that bilirubin induces intestinal secretion without producing intestinal lactase deficiency and have proposed that acute intestinal secretion, not lactase deficiency, is the mechanism of diarrhea occurring during jaundice phototherapy (23). In this work, the effect of phototherapy on intestinal mucosal bilirubin concentration and lactase activity in the Gunn rat is investigated to resolve some of the previously stated conflicts.

\section{MATERIALS AND METHODS}

Gunn-strain, homozygous ( $\mathrm{jj})$ and heterozygous $(\mathrm{Jj})$ rats weighing 250 to $400 \mathrm{~g}$ were given pentobarbital sodium $(40 \mathrm{mg} / \mathrm{kg}$ body weight) anesthesia. The hair was removed from the dorsal and lateral skin by an electric clipper and a commercial depilatory agent, and $2 \mathrm{ml}$ blood were obtained by tail section. Rats were returned to their cages for $24 \mathrm{hr}$ before the treatment schedule began. Ten groups of six or seven animals each (Table 1) were studied. $\mathrm{Jj}$ and $\mathrm{jj}$ animals were given 24,48 , or $72 \mathrm{hr}$ of continuous phototherapy, and $\mathrm{Jj}$ and $\mathrm{jj}$ animals were given $24-$ and $48-\mathrm{hr}$ sham control treatments. The notation to be used subsequently gives the genotype, duration of therapy, and type of therapy, i.e., $\mathrm{Jj} 24 \mathrm{p}$ is heterozygous, was treated for $24 \mathrm{hr}$ and received phototherapy, and $\mathrm{Jj} 24 \mathrm{c}$ is an equivalent sham control.

A wire cage was constructed for the irradiance exposure. It was suspended to prevent coprophagia; it was open on all sides to allow for adequate ventilation and to prevent excessive heat trapping; it was divided to provide separate quarters for two rats to be irradiated in identical fashion; water was provided through metal nipples which entered the cage on the side and did not block light exposure; and food was provided, except for the last 24 $\mathrm{hr}$ of treatment, by a centrally placed feeder which did not block light exposure. Sham control animals were maintained in usual animal quarters, and food was withheld for the last $24 \mathrm{hr}$ of the period. Phototherapy was provided by a bank of eight fluorescent tubes, four Westinghouse Special Blue (F20T12/BB) alternating with four Westinghouse Daylight (F20T12/D), which gave an incident radiant energy of $1.2 \mathrm{~mW} / \mathrm{cm}^{2}$ at the bottom of the cage. The average light was measured by an International Light IL-444 Phototherapy Radiometer equipped with a narrow-band pass acceptance filter with peak acceptance at $460 \mathrm{~nm}$.

When the phototherapy or control period ended, the animal was anesthetized with ether and was killed by cervical dislocation. Posttreatment blood was obtained by tail section and by free flow 
WHITINGTON

Table l. The effect of treatment on weight, hematocrit and serum bilirubin concentration

\begin{tabular}{|c|c|c|c|c|c|c|c|c|c|c|}
\hline Groups & $\begin{array}{r}\mathrm{Jj} 24 \mathrm{p} \\
(6)^{1}\end{array}$ & $\begin{array}{l}\mathrm{jj} 24 \mathrm{p} \\
(6)\end{array}$ & $\begin{array}{l}\mathrm{Jj} 24 \mathrm{c} \\
(6)\end{array}$ & $\begin{array}{l}\mathrm{jj} 24 \mathrm{c} \\
(6)\end{array}$ & $\begin{array}{l}\mathrm{Jj} 48 \mathrm{p} \\
(6)\end{array}$ & $\begin{array}{l}j j 48 p \\
(7)\end{array}$ & $\begin{array}{l}\mathrm{Jj} 48 \mathrm{c} \\
(6)\end{array}$ & $\begin{array}{c}j \mathrm{j} 48 \mathrm{c} \\
(6)\end{array}$ & $\begin{array}{l}\mathrm{Jj} 72 \mathrm{p} \\
(6)\end{array}$ & $\begin{array}{l}\mathrm{jj} 72 \mathrm{p} \\
(6)\end{array}$ \\
\hline $\begin{array}{l}\text { Fractional weight } \\
\text { change }^{2}\end{array}$ & $\begin{array}{l}-0.11 \\
\pm 0.04^{3}\end{array}$ & $\begin{array}{l}-0.11 \\
\pm 0.02\end{array}$ & $\begin{array}{r}-0.11 \\
\pm 0.02\end{array}$ & $\begin{array}{l}-0.11 \\
\pm 0.05\end{array}$ & $\begin{array}{r}-0.13 \\
\pm 0.05\end{array}$ & $\begin{array}{r}-0.13 \\
\pm 0.03\end{array}$ & $\begin{array}{l}-0.11 \\
\pm 0.03\end{array}$ & $\begin{array}{r}-0.11 \\
\pm 0.03\end{array}$ & $\begin{array}{l}-0.16 \\
\pm 0.03\end{array}$ & $\begin{array}{r}-0.22 \\
\pm 0.03\end{array}$ \\
\hline $\begin{array}{l}\text { Fractional hematocrit } \\
\text { change }^{2}\end{array}$ & $\begin{array}{r}-0.18 \\
\pm 0.12\end{array}$ & $\begin{array}{r}-0.18 \\
\pm 0.14\end{array}$ & $\begin{array}{l}-0.10 \\
\pm 0.09\end{array}$ & $\begin{array}{r}-0.10 \\
\pm 0.08\end{array}$ & $\begin{array}{l}-0.11 \\
\pm 0.06\end{array}$ & $\begin{array}{l}-0.15 \\
\pm 0.09\end{array}$ & $\begin{array}{l}-0.16 \\
\pm 0.10\end{array}$ & $\begin{array}{l}-0.15 \\
\pm 0.05\end{array}$ & $\begin{array}{l}-0.06 \\
\pm 0.10\end{array}$ & $\begin{array}{l}-0.11 \\
\pm 0.07\end{array}$ \\
\hline $\begin{array}{l}\text { Pretreatment serum bili- } \\
\text { rubin }(\mu \mathrm{M})\end{array}$ & $\begin{array}{r}4.70 \\
\pm 5.00\end{array}$ & $\begin{array}{r}103.74 \\
\pm 11.53\end{array}$ & $\begin{array}{r}4.25 \\
\pm 3.65\end{array}$ & $\begin{array}{r}111.70 \\
\pm 22.34\end{array}$ & $\begin{array}{r}0.99 \\
\pm 0.35\end{array}$ & $\begin{array}{r}103.03 \\
\pm 24.21\end{array}$ & $\begin{array}{r}5.53 \\
\pm 3.78\end{array}$ & $\begin{array}{r}106.23 \\
\pm 21.48\end{array}$ & $\begin{array}{r}1.13 \\
\pm 0.44\end{array}$ & $\begin{array}{r}107.00 \\
\pm 32.73\end{array}$ \\
\hline $\begin{array}{l}\text { Posttreatment serum bil- } \\
\text { irubin }(\mu \mathrm{M})\end{array}$ & $\begin{array}{r}2.93 \\
\pm 2.61\end{array}$ & $\begin{aligned} & 48.16 \\
\pm & 18.08^{4}\end{aligned}$ & $\begin{array}{r}0.99 \\
\pm 0.35\end{array}$ & $\begin{array}{l}140.40 \\
\pm 20.27^{5}\end{array}$ & 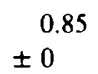 & $\begin{array}{r}42.28 \\
\pm 12.04^{4}\end{array}$ & $\begin{array}{r}3.11 \\
\pm 3.07\end{array}$ & $\begin{array}{r}123.04 \\
\pm 26.93\end{array}$ & $\begin{array}{r}0.99 \\
\pm 0.35\end{array}$ & $\begin{array}{r}33.95 \\
\pm 18.26^{4}\end{array}$ \\
\hline
\end{tabular}

' Numbers in parentheses, number of animals.

${ }^{2}$ Fractional change $=($ final value - initial value $) /$ initial value.

${ }^{3}$ Mean \pm S.E.

${ }^{4} P<0.001$ as compared to pretreatment value, paired $t$ test; all others not significant.

${ }^{5} P<0.01$.

from neck vessels. The abdomen was immediately opened, and the small intestine was removed, divided into proximal (jejunum) and distal (ileum) halves, and placed in ice-cold isotonic phosphate-buffered saline, $\mathrm{pH} 7.4$ (PBS). The halves were individually flushed with $20 \mathrm{ml}$ cold PBS, inverted, agitated in cold PBS to remove adhering mucous, and blotted dry on paper towels. The mucosa was scraped from the bowel, weighed, appropriately diluted with PBS, and homogenized by a Tekmar tissue homogenizer set at $20,000 \mathrm{rpm}$ for $30 \mathrm{sec}$. Aliquots were taken for measurement of tissue bilirubin concentration, disaccharidase activities, and protein concentration. Bilirubin concentrations were always determined on fresh samples, but disaccharidase activity and protein were measured using tissue which had been stored at $-20^{\circ} \mathrm{C}$ for less than 2 wk. Tissue was prepared in dim tungsten lighting and was protected from light when possible. Animals were killed between 11:00 and 13:00 to minimize the effect of the circadian rhythm upon disaccharidase activity (20).

Serum bilirubin concentrations were measured on samples obtained $24 \mathrm{hr}$ before and at the termination of treatment by the method of Malloy and Evelyn (13). The results are expressed as $\mu \mathrm{M}$. The lowest limit of detection was $0.85 \mu \mathrm{M}$; this value was recorded for all samples with bilirubin concentrations below detection. Tissue bilirubin was measured by reacting with diazotized $p$-iodoaniline and expressed as $\mu \mathrm{g} / \mathrm{g}$ wet mucosa (9). Disaccharidase activities were determined by the method of Dahlquist (4) using lactose and sucrose as substrates and expressed as $\mu$ mole glucose liberated $/ \mathrm{min} / \mathrm{g}$ tissue protein (units/g).

In preliminary studies, bilirubin was added in vitro to normal $\mathrm{Jj}$ jejunal mucosal homogenates at a final concentration of $10 \mu \mathrm{g} / \mathrm{g}$ mucosa to determine if it would inhibit or interfere with the determination of lactase activity. Because the colorimetric endpoint of the glucose oxidase reaction is determined at $500 \mathrm{~nm}$ and because bilirubin absorbs at this wavelength, bilirubin does interfere with the disaccharidase assay. To exclude this error, reaction blanks for each sample were prepared. They were held on ice during the incubation period and reacted with the glucose oxidase reagent in parallel with the reaction sample determination. The absorbance at $500 \mathrm{~nm}$ for the blank was subtracted from that for the reaction sample, and the activity was calculated from the difference. Using this method, the values obtained in six preparations with added bilirubin were $16.76 \pm 2.82(\bar{x} \pm$ S.D.) units $/ g$ protein and were not different from the preparations without added bilirubin, $16.75 \pm 2.46(t=0.072 ; P>0.90)$.

Protein was measured by a modification of the method of Lowry using bovine serum albumin as a standard (21). A capillary tube hematocrit was done on pre- and posttreatment blood.

Student's $t$ test was used to analyze differences between group means, and the $t$ test for paired samples was used when appropriate to analyze differences within a group.

\section{RESULTS}

Table 1 gives the fractional weight change, fractional hematocrit change, and the serum bilirubin concentrations before and after treatment. Previous experience indicated that prolonged phototherapy would result in significant weight loss because of anorexia and enhanced insensible water loss (17), which would affect $j j$ animals because they cannot concentrate their urines (16). A progressively increasing fractional weight loss was observed in treated animals as the length of exposure increased, reaching statistical significance in $\mathrm{jj} 72 \mathrm{p}(P<0.001)$; control animals at 24 and $48 \mathrm{hr}$ and $24-\mathrm{hr}$ treated groups were not different. Three components of treatment could affect the fractional hematocrit change: pretreatment blood drawing in all groups, hemolysis in $\mathrm{jj}$ animals consequent to irradiance (3), and hemoconcentration from dehydration which would largely affect treated jj animals (16). No significant difference was demonstrated among the groups, but the fractional hematocrit change appeared to vary inversely with the fractional weight change in the light-treated groups. The serum bilirubin concentrations in $\mathrm{jj}$ animals before and after phototherapy were higher than comparable $\mathrm{Jj}$ animals $(P<0.001)$. Phototherapy significantly reduced the serum bilirubin concentration of $\mathrm{jj}$ animals but had no effect on $\mathrm{Jj}$ animals. An increase in serum bilirubin concentration with treatment was noted in $\mathrm{jj} 24 \mathrm{c}$ and $\mathrm{jj} 48 \mathrm{c}$, probably as a consequence of fasting for $24 \mathrm{hr} \mathrm{(22).}$

The mucosal bilirubin concentrations (Table 2) were measured independently in jejunum and ileum because jejunum was expected to have greater exposure to intraluminal bilirubin during phototherapy and might be expected to reflect phototherapy induced changes with greater sensitivity than would whole gut mucosa. The mean jejunal bilirubin concentration was higher than ileal in every jj group (paired $t$ test: jj24p, $P<0.01 ; \mathrm{jj} 24 \mathrm{c}, P$ $<0.1$; jj48p, $P<0.001$; jj48c, $P<0.01$; jj72p, $P<0.02$ ), but no difference was observed in $\mathrm{Jj}$ animals except in $\mathrm{Jj} 24 \mathrm{p}$ where the concentration in ileum exceeded that in jejunum $(P<0.1)$. Phototherapy caused a reduction $(P<0.1)$ in jejunal bilirubin concentration in jj24p and jj48p as compared to jj24c and jj48c; the ileal response was not significant. No effect was observed in $\mathbf{J j}$ animals.

The activities of lactase and sucrase (Table 3) were measured separately in jejunum and ileum. The activities are expressed as units/g protein, and because variation in the removal of mucosa from the gut with more or less inclusion of submucosa and muscularis could alter the denominator, the ratio of lactase to sucrase activity $(\mathrm{L} / \mathrm{S})$, which would be unaffected by tissue preparation, was also calculated for each animal. As expected, the activity of each disaccharidase was higher in jejunum than in ileum, but $\mathrm{L} / \mathrm{S}$ was not different. The lactase activity of jejunum 
Table 2. Mucosal bilirubin concentration $(\mu \mathrm{g} / \mathrm{g})$

\begin{tabular}{|c|c|c|c|c|c|c|}
\hline \multirow[b]{2}{*}{ Groups } & \multicolumn{2}{|c|}{$24 \mathrm{hr}$} & \multicolumn{2}{|c|}{$48 \mathrm{hr}$} & \multicolumn{2}{|c|}{$72 \mathrm{hr}$} \\
\hline & Jejunum & Ileum & Jejunum & Ileum & Jejunum & Ileum \\
\hline Jjp & $0.39 \pm 0.40^{\prime}$ & $1.29 \pm 1.27$ & $0.69 \pm 0.37$ & $0.66 \pm 0.60$ & $1.01 \pm 0.48$ & $1.59 \pm 1.51$ \\
\hline jjp & $4.72 \pm 1.78$ & $3.88 \pm 2.68$ & $7.33 \pm 3.15$ & $4.17 \pm 2.47$ & $6.30 \pm 4.23$ & $3.31 \pm 2.31$ \\
\hline $\mathrm{Jjc}$ & $0.52 \pm 0.37$ & $0.79 \pm 1.25$ & $0.39 \pm 0.44$ & $0.76 \pm 0.42$ & & \\
\hline $\mathrm{jjc}$ & $8.23 \pm 2.01$ & $5.26 \pm 1.62$ & $10.60 \pm 2.62$ & $6.60 \pm 1.89$ & & \\
\hline
\end{tabular}

${ }^{\prime}$ Mean \pm S.D.

Table 3. Lactase activity (units/g protein), sucrase activity, and the ratio of lactase to sucrase activity in jejunum and ileum

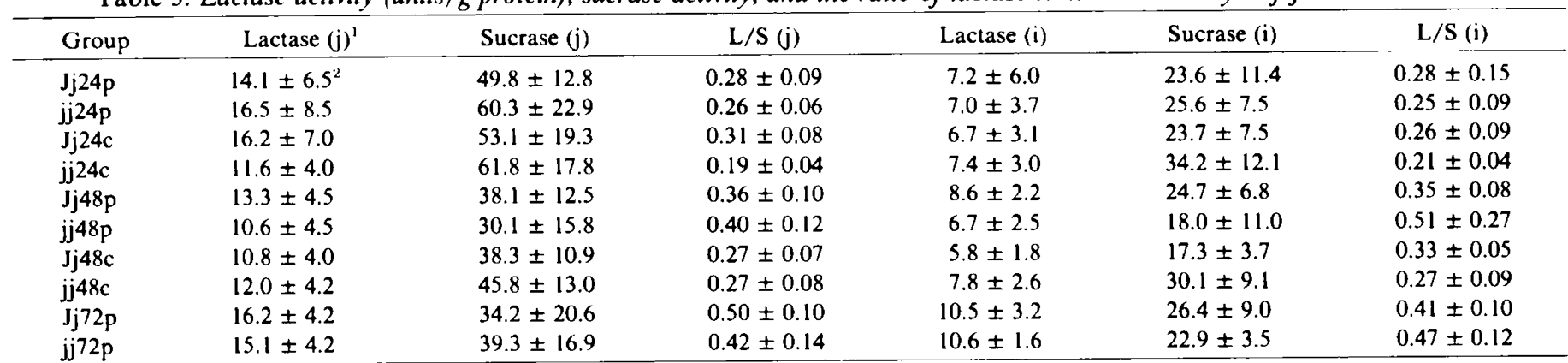

'j. jejunum; i, ileum.

${ }^{2}$ Mean \pm S.D.

and ileum of jip as compared to Jjp and jjc at 24 and $48 \mathrm{hr}$ and as compared to Jjp at $72 \mathrm{hr}$ was never depressed. L/S also failed to illustrate any reduction in lactase activity consequent to phototherapy; rather, the ratio was higher in Jj48p, jj48p, Jj72p, and jj $72 \mathrm{p}(P<0.1)$ than in $\mathrm{Jj} 48 \mathrm{c}$ and jj48c.

\section{DISCUSSION}

A central role in the pathogenesis of diarrhea associated with jaundice phototherapy has been ascribed to secondary lactase deficiency; work involving six jaundiced newborn infants is responsible for this concept (1). These infants had blunted blood glucose rises in response to intragastric instillation of lactose, $2 \mathrm{~g} /$ $\mathrm{kg}$ body weight, they had abnormal stools which improved with administration of a lactose-free infant formula, and they had abnormally low levels of mucosal lactase activity in intestinal biopsies. These data appear to convincingly implicate lactase deficiency in jaundice phototherapy-induced diarrhea, but a number of questions must be raised about their interpretation. First, all presumably had physiologic jaundice, but because they were all studied in the second or third day of life, this diagnosis seems questionable (15). In the absence of hemolysis, a reason for their jaundice could have been delayed gastric emptying with an enhanced enterohepatic circulation for bilirubin (15), which could also explain blunting of the lactose tolerance test (11). Secondly, a blunted lactose tolerance curve appears to typify infants less than 3 days old; it is doubtful that data from these infants could be statistically separated from that obtained in normal newborn infants of the same age (2), the study controls being more typical of infants older than I wk. Finally, control data for the histochemical lactase determination is lacking; control patients should include normal and jaundiced newborns without phototherapy because bilirubin added in vitro resulted in inhibition of lactase activity in this system (1).

These studies were undertaken to clarify the relationship of phototherapy to lactase deficiency. Because the Gunn rat presumably developed lactase deficiency consequent to phototherapy (5), this animal was used. The results indicate that intensive irradiance resulted in significant reduction in serum bilirubin and presumably excretion of bilirubin into the gut (18). However, phototherapy did not depress intestinal lactase activity. An increase in L/S occurred with prolonged phototherapy exposure in both $\mathrm{jj}$ and $\mathrm{Jj}$, most likely resulting from alteration in the circadian rhythm while under constant irradiance (20). The data convincingly demonstrate that the Gunn rat does not develop lactase deficiency consequent to phototherapy.

We measured the concentration of bilirubin in the intestinal mucosa because jaundice phototherapy in human neonates was reported to cause accumulation of bilirubin in the mucosa and, consequently, mucosal injury (1). Both jjc and jjp had visibly icteric intestinal mucosa, but the mucosal concentration was reduced by phototherapy in jjp. This occurrence further illustrates the need for control small bowel biopsies from icteric infants without phototherapy when interpreting those from infants with phototherapy. Mucosal bilirubin concentration did not vary inversely with length of irradiance. Therefore, the increased mucosal lactase activity after prolonged phototherapy was not related to reduced mucosal bilirubin concentration.

These data do not support the role of lactase deficiency in the pathogenesis of diarrhea associated with jaundice phototherapy. Moreover, lactose tolerance tests have been done in a large number of infants treated with light, and they were normal, further mitigating against secondary lactase deficiency $(6,7)$. We have shown that nonconjugated bilirubin is a powerful inducer of intestinal secretion (23), and because nonconjugated bilirubin is present in significant concentrations within the intestinal lumen of lighttreated neonates (12), a similar effect is proposed to be important in the mechanism of the diarrhea of jaundice phototherapy.

\section{REFERENCES AND NOTES}

1. Bakken, A. F.: Temporary intestinal lactase deficiency in light-treated jaundiced infants. Acta Paediatr. Scand., 66: 91 (1977).

2. Boellner, S. W. Beard, A. G., and Panos, T. C.: Impairment of intestinal hydrolysis of lactose in newborn infants. Pediatrics, 36: 542 (1965).

3. Cukier, J. O.. Maglalang, A. C., and Odell, G. B.: Increased osmotic fragility of erythrocytes in chronically jaundiced rats after phototherapy. Acta Paediatr. Scand., 68: 903 (1979).

4. Dahlqvist. A.: Assay of intestinal disaccharidases. Anal. Biochem., 22: 99 (1968).

5. Dinari, G., Daum. F. Cohen, M. I.. and McNamara, H.: Effects of phototherapy on intestinal disaccharidase activity in the rat. Pediatr. Res., 11: 443 (1977).

6. Ebbesen, F., Edelsten, D., and Hertel, J.: Gut transit time and lactose malabsorption during phototherapy: I. A study using lactose-free human mature milk. Acta Paediatr. Scand.. 69: 65 (1980).

7. Ebbesen, F., Edelsten, D., and Hertel, J.: Gut transit time and lactose malab- 
sorption during phototherapy: II. A study using raw milk from the mothers of the infants. Acta Paediatr. Scand. 69: 69 (1980).

8. Final report of the committee on phototherapy in the newborn. Commituee on Phototherapy in the Newborn. Division of Medical Sciences. Assembly of Life Sciences, National Research Council. National Academy of Sciences, Washington. D. C., (1974)

9. Heirwegh, K. Fevery, J., Meuwissen, A., de Groote, J., Campernolle, F., Desmet, $V$. and van Roy, F. Recent advances in the separation and analysis of diazopositive bile pigments. In: D. Glick: Methods of Biochemical Analysis. Vol. 22 positive bile pigments. In: D. Glick: Methods of Bioch
p. 205 (John Wiley \& Sons, Inc.. New York. 1974)

10. John. E.: Complications of phototherapy in neonatal hyperbilirubinemia. Aust. Paediatr. J., 11: 53 (1975).

11. Krasilnikf, P. Audmand-Høyer, E., and Moltke, H. H.: Diagnostic value of disaccharide tolerance tests in children. Acta Paediatr. Scand.. 64: 693 (1975).

12. Lund, H. T., and Jacobsen, J.: Influence of phototherapy on unconjugated bilirubin in duodenal bile of newborn infants with hyperbilirubinemia. Acta Paediatr. Scand., 61: 693 (1972)

13. Malloy, H. and Evelyn, K.: The determination of bilirubin with the photoelectric colorimeter. J. Biol. Chem., 119: 481 (1937).

14. McDonagh, A. F., and Ramonas, L. M.: Jaundice phototherapy: micro flow-cell photometry reveals rapid biliary response of Gunn rats to light. Science (Wash. D. C.), 201: 829 (1978).

15. Odell, G. B., Cukier, J. O., and Maglalang. A. C.: Pathogenesis of neonatal hyperbilirubinemia In: D. S. Young, J. M. Hicks: The Neonate: Clinical Biochemistry, Physiology, and Pathology. p. 271 (John Wiley and Sons. New York. 1976)

Copyright (ㄷ) 1981 International Pediatric Research Foundation, Inc. $0031-3998 / 81 / 1504-0345 \$ 02.00 / 0$
16. Odell, G. B., Natzschka, J. C., and Storey, G. N. B.: Bilirubin nephropathy in the Gunn strain of rat. Am. J. Physiol., 212: 931 (1967).

17. Oh, W., and Karecki, H.: Phototherapy and insensible water loss in the newbor infant. Am. J. Dis. Child., 124: 230 (1972).

18. Ostrow. J. D. Photocatabolism of labeled bilirubin in the congenitally jaundiced (Gunn) rat. J. Clin. Invest.. 50: 707 (1971).

19. Rubatelli, F. F., and Largajolli, G.: Effect of light exposure on gut transit time in jaundiced newborns. Acta Paediatr. Scand., 62: 146 (1973).

20. Stevenson. N. R., and Fierstein. J. S.: Circadian rhythms of intestinal sucrase and glucose transport: cued by time of feeding. Am. J. Physiol., 230: 731 (1976).

21. Sutherland, E. W., Cori, C. F., Haynes, R., and Olsen. N. S.: Purification of the hyperglycemic-glycogenolytic factor from insulin and from gastric mucosa. J. Biol. Chem., 180: 825 (1949)

22. Thaler, M. M. and Dawber, N. H.: Stimulation of bilirubin formation in liver of newborn rats by fasting and glucagon. Gastroenterology, 72: 312 (1977).

23. Whitington, P. F.: Small bowel secretion induced by unconjugated bilirubin Pediatr. Res., 12: 443 (1978)

24. Requests for reprints should be addressed to: Peter F. Whitington, M.D., University of Tennessee CHS, Room 550 Dobbs Research Building, Memphis, TN 38163 (USA).

25. This research was supported by a University of Tennessee New Faculty Research Grant H-00039.

26. Received for publication May 9, 1980

27. Accepted for publication August 13,1980. 